\title{
Instructional Model of Self-defense Lesson in Physical Education: A systematic Review
}

\author{
Nur Rohmah Muktiani \\ Faculty of Sports Sciences \\ Universitas Negeri Yogyakarta \\ Yogyakarta, Indonesia \\ nur_rohmah@uny.ac.id \\ Saryono \\ Faculty of Sports Sciences \\ Universitas Negeri Yogyakarta \\ Yogyakarta, Indonesia \\ saryono@uny.ac.id
}

\author{
Erlina Listyarini \\ Faculty of Sports Science \\ Universitas Negeri Yogyakarta \\ Yogyakarta, Indonesia \\ erlina@uny.ac.id \\ Soni Nopembri \\ Faculty of Sports Sciences \\ Universitas Negeri Yogyakarta \\ Yogyakarta, Indonesia \\ soni_nopembri@uny.ac.id
}

\begin{abstract}
-martial art (self-defense learning) is a unique discipline in physical education which requires a separate approach and instructional model in order to be beneficial to the student and serve the purpose of physical education. Hence, this study aims to analyze various research results related to the use of approaches and instructional models of self-defense lessons in the physical education program. About 80 articles published online from 40 local and 40 international journals were analyzed. In this study, the Interactive model (data collection, display, and conclusion/verification) from Miles and Huberman (1984) was used to analyze data. The study found many approaches and instructional models of martial arts related to education/pedagogy in physical education in Indonesia and many other countries. Internationally, there are three types of self-defense instructional models in physical education. They include the instructional models that emphasize culture, sports, and students' self-development aspects. Nationally, self-defense learning in physical education uses Mosston's teaching style, general and special instructional models which lay a strong emphasis on character building. The instructional model of self-defense is expected to meet the competencies from aspects of knowledge, attitudes, and skills.
\end{abstract}

Keywords—martial arts, instructional, physical education

\section{INTRODUCTION}

Over the years, Physical education learning has undergone rapid development. Inventions and numerous studies were conducted to develop a more creative and attractive physical education learning which still serves the original purpose of physical education [1]. A paradigm shift in the education purpose was followed by the change in the purpose of physical education. This shifting phenomenon has apparently affected the development of the learning approach to physical education. Hence, the purpose and learning of physical education should be harmonious. Historically and philosophically, physical education has transformed in Indonesia and all over the world. Even up till this day, people still argue over the science of physical education itself. In some countries, physical education has become an excellent national program which is very beneficial to people. In Indonesian school curriculum, Physical education has formally been a part of it. However, people's mixed up understanding of physical education, sports, recreation, physical activities, and health makes physical education bias in the eyes of our communities.

Learning in physical education was developed from Sweden and Germany gymnastics systems. Both systems were extensively incorporated in many physical education programs across the world. However, since the systems were more teacher-centered, students were mainly followers of their teachers with a goal to master all materials and techniques. This existed primarily due to the fact that past physical education focused on gymnastics learning materials. As teaching materials transformed from gymnastics to sportbased, new teaching methods began to emerge in the early 1960s [2-3]. Since then, various new methods for teaching physical education arose and are currently known as teaching strategies. Some of them include task/station teaching, reflective teaching, partner teaching, team teaching, and inquiry-based teaching [4].

Martial arts or self-defense learning is a major material in physical and sport education. Martial arts can be found across several Asian countries. Of all types of martial arts, pencak silat, originating from Indonesia, is one of the most popular types of sports in Southeast Asia. The Indonesian pencak silat has become a worldwide Google trending search in 18 countries. Additionally, the martial arts topic happens to be quite a fascinating topic across the world. In survey, the Indonesian martial art is the $25^{\text {th }}$ most searched topic across 56 countries. Furthermore, the Pencak silat martial art has developed through many ways including schools. In schools, pencak silat is taught as recommended by the 2013 Indonesian national curriculum (K-13). In the curriculum, the methods of martial arts vary in learning. The 2013 Physical Education, Sport, and Health (PJOK) Curriculum has recommended the adoption of various methods, strategies, and models in the process learning pencak silat martial art. Hence, there is a vital need to investigate models 
adopted in teaching martial arts as part of physical and sport education all across the world.

Findings of studies in Southeast Asia reports that the origin of martial arts is characteristically different and that three learning approaches exists namely; traditional, efficiency, and sports [5]. In addition, the data also indicates the practice of martial arts as part of physical education in schools across several European countries [5]. Hence, this study aims to investigate and analyze the adoption of martial art learning models in physical education which is studied in numerous scientific articles published in either national or international journals.

\section{METHOD}

\section{A. Research Design}

This study was performed applying a Meta-Analysis which simply means an analysis over analyses. As an effective research method, the meta-analysis assesses the results of previous research studies in a similar topic. The meta-analysis was first adopted in the research on health/medication. With time, the meta-analysis was adopted to study various problems/topics. Meta-analysis is a synthesis of topics from multiple research results. Synthesis is the basis for drawing conclusion on the topic being studied. A metaanalysis consists of several stages including; determining the problem or topic of the study, defining the research period, gathering research reports on the topic/problem being studied, reading research titles and abstracts, focusing on problems, methods, data analyses, and results, categorizing research results, comparing all results based on their categories, studying research methods and data analyses, and drawing conclusions [6].

\section{B. Unit Analysis}

The Analysis unit in this study consists of 80 articles published in national or international journals which presented ideas and results of the research on martial art learning models. The samples were selected using a purposive sampling technique where the topic or theme of the articles are related to learning martial arts in physical and sport education. Under such requirement, 41 articles comprising of 21 international articles and 20 national articles were considered eligible for the study.

\section{Data Collection}

The researchers themselves through a self-evaluation process validate the human Instrument as to what extent the researchers understand the qualitative method, theories, and insights into the field of study, as well as readiness and provision for the field study [7]. After setting the study focus, simple research instruments were developed in order to complete and compare data previously gathered. The Data was collected using the guided documentation technique and according to data source. Primary data is data collected firsthand from the original source. The Primary data in this study include opinions, ideas, and research results from journal articles about martial art learning models in physical and sport education. Data is valid if there is no difference between the report and the current study. To test the validity of data, this study conducted a credibility test (internal validity), transferability test (external validity), dependability test (reliability), and confirmability test (objectivity) [7].

\section{Data Analysis}

A qualitative data analysis technique using interactive model proposed by Miles and Huberman [8] was applied in this study. Additionally, Miles and Huberman recommended several activities for data analysis which includes; data collection, data display, and data conclusion drawing/verification. In research, data reduction is a process that involves selecting, focusing, conceptualizing and converting raw data in the field notes. In qualitative research, data is displayed in form of brief description, charts, relationship between categories, flowcharts, and many more [7]. Meanwhile, the conclusion proposed in a qualitative research is considered temporary and changes when stronger supporting evidences are absent from the subsequent stages.

\section{RESULTS}

\section{A. Study of Martial Art Learning Model across the World}

This research studied 21 journals written by martial arts researchers across the world. The journal documents in study originated from several international journals from 1990 to 2017. The United States of America began conducting numerous researches on martial art learning and was followed by many other countries including Belgium, China, Spain, Singapore, Mexico, England, Iran, Poland, Canada, and Latvia. Most researchers studied the practice of all types of martial arts, specifically Judo, Taekwondo, Wushu, Karate, and Pencak Silat. Some researchers also studied Mixed Martial Arts.

The Martial art learning and training in this study is related to various aspects of the participants such as the physical, psychological, and sociological aspects. Some variables were also related to the mastery of the techniques. In addition, some researchers also studied violence and risk factors for injury in martial arts. In the context of martial art learning practice, most researchers studied physical education in primary and secondary schools.

Findings from the articles published in several international journals suggest three types of model/approach to martial art learning. The first model laid emphasis on cultural aspects such as traditional, sociological, socialeconomical, anthropological, humanist, cultural, multicultural, authoethnographical, and academic approaches. The second model emphasizes sport aspects such as competitive, Leadership Education through Athletic Development (LEAD), N/M/M (Nomometic/ Monitoring/ Multidimensional) approach, and belt color system. Meanwhile, the third model emphasizes on the student development aspects such as comfort, control, price, selfactualization, and problem-based approaches.

\section{B. Study of Martial Art Learning Model in Indonesia}

From the 20 national journals being studied more updated findings were found from researches in the 2013-2018 period. Furthermore, because pencak silat obviously listed in the curriculum, researchers in the context of physical and sport education often study one type of martial arts. Although being 
part of physical education, sport, and a health subject in Indonesia, martial arts is taught one or two times in a semester. This phenomenon attracts researchers to implement various models/approaches to martial art learning on different educational levels. According to the journal articles, researchers found the adoption of Mosston's teaching style, general learning models, and special learning model that emphasize the character building in martial art learning as part of physical and sport education. The adopted Mosston's styles include the Guided Discovery, exercises, inclusion, and reciprocal styles. The general learning models that are often studied include cooperative, direct institution, individual, group, and couple of models. Meanwhile, the special models/methods/approaches include playing, multimediabased method, pencak silat gymnastics, and character building in pencak silat.

\section{DISCUSSION}

The learning of martial art emphasizing on cultural aspects views martial arts as an art of defending oneself from threats and dangers. This artwork has been developed into a function to improve one's physical condition, social connection, trading, partnership, and cultural acculturation. In today's education, martial arts emerged to balance the dominance of dualism mind/body [9]. Martial art was originally a type of ancient fighting which was later modified into sports [10].

From some of the articles, it was found that martial art learning focused on its sport-related aspect. For example, martial arts have been transformed into sports in form of competitions. Martial arts show unique body movements which work harmoniously with the development of mental and spiritual aspects such as characters, feelings, medication, and many more. As the characteristics of competitive martial arts demonstrate demands of sport, they require the development of specific training program [11]. For example, karate is considered as one of sports that promotes health, education, and rehabilitation management [12] as well as optimizes the quality of basic and specific motor skill performances needed by young athletes to participate in the competition [13]. In general, the findings suggest that martial art competitions are characterized by high aerobic and anaerobic responses [14].

Martial art learning is directed toward the development of various aspects of the lives of students. It involves not only physical but also psychological, social, and spiritual aspects. The possible effect of martial arts on psychological and social aspects is still an interesting research topic [15]. As a form of education, martial art has fulfilled both the psychological and physical needs and has used the body as a tool for enlightenment and wisdom in the spiritual aspects [16]. Martial art training also shows interaction and implication in the development of students' self-management [17]. Besides its health benefit, another benefit of martial arts includes its psychological balance and wellness that helps to reduce aggressiveness [10].

The development of martial art learning should better be pointed towards constructivist-based learning models. The Constructivist perspective is a learning theory lays emphasis on students' experiences, not merely on their cognitive knowledge [18]. For example, pencak silat martial art learning requires a learning model that is able to improve students' motoric skill and therefore, the game approach can increase the academic results of students [19]. Furthermore, a character-based learning model applied in pencak silat can be used as an approach to physical education in primary schools. The adoption of such model prevents physical education from being conventional and orientated toward martial arts and sport aspects only [20].

\section{CONCLUSION}

The international journal findings suggest three types of model or approach to self-defense learning used in physical and sport education, which include (1) culture-centered selfdefense learning model/approach, (2) sport-centered selfdefense learning model/approach, and (3) student-centered self-defense learning model/approach. In the meantime, the national journal findings demonstrate the adoption of Mosston teaching style, general learning models, and special learning model focusing on character building in self-defense learning as part of physical and sport education. Self-defense learning tries to help students to learn martial arts and to reach competences that cover knowledge, skill, and aspects of attitude. These aspects make this topic fascinating for study. The various aspects to study affect not only the method but also the material delivery model, which influences the object and variation type.

\section{ACKNOWLEDGMENT}

This work supported by Research Group Grant 2018 from Faculty of Sport Sciences, Universitas Negeri Yogyakarta.

\section{REFERENCES}

[1] C.A. Bucher, Foundation of Physical Education. St. Louis: C.V. Mosby Company, 1995

[2] M. Mosston and S. Ashworth, Teaching Physical education. New York: Macmillan Publishing company, 1992:

[3] M. Mosston ans S. Ashworth, Teaching Physical Education 4rt Ed. New York: Macmillian College Publishing, 1994.

[4] M. W. Metzler, Instructional Models for Physical Education. Massachusetts: Allyn and Bacon, A Person Education Company, 2000.

[5] M. Theeboom and P. De Knop, "Asian martial arts and approaches of instruction in physical education," European Journal of Physical Education, vol. 4, no. 2, pp. 146-161, 1999.

[6] R. A. Merriyana, "Meta analisis penelitian alternatif bagi guru," Jurnal Pendidikan Penabur, vol. V, no.06, June 2006.

[7] Sugiyono, Memahami Penelitian Kualitatif. Bandung: Alfabeta, 2005.

[8] M. B. Miles and A. M. Huberman, Qualitative data analysis. London: Sage, 1984.

[9] D. Brown and A. Johnson, "The social practice of self- defense martial arts: applications for physical education," Quest, vol. 52, no.3, pp.246259, 2000.

[10] T. W. Woodward, "A review of the effects of martial arts practice on health,” Wisconsin Medical Journal, vol. 108, no. 1, pp. 40-43, 2009.

[11] M. N. M. Shapie, J. Oliver, P. O’Donoghue, and R. Tong, "Activity profile during action time in national silat competition," Journal of Combat Sports and Martial Arts, vol. 4, no. 1(2), pp. 81-86, 2013.

[12] W. Mastnak, "Karate: interdisciplinary perspectives and benefits for health. Journal of Combat Sports and Martial Arts, vol. 7, no. 2(2), pp. 127-132, 2016.

[13] J. Jukić, M. Čavala, R. Katić, N. Zagorac, and S. Blažević, "Morphological, motor and technical determinants of fighting efficiency in croatian cadet karate athletes," Journal of Combat Sports and Martial Arts, vol. 8, no. 2(2), pp. 127-134, 2017. 
[14] A. R. Aziz, B. Tan, and K. C. Teh, "Physiological responses during matches and profile of elite pencak silat exponents," Journal of Sports Science and Medicine, vol. 1, pp. 147-155, 2002.

[15] J. Vertonghen and M. Theeboom, "The social-psychological outcomes of martial arts practise among youth: A review," Journal of Sports Science and Medicine, vol. 9, pp. 528-537, 2010.

[16] W. Cynarski, K. Obodyńsk, H. Z. Zeng, "Martial arts anthropology for sport pedagogy and physical education," Romanian Journal for Multidimensional Education, vol. IV, no. 2, pp. 129-152, August 2012.

[17] K. D. Lakes and W. T. Hoyt, "Promoting self-regulation through school-based martial arts training," Applied Developmental Psychology, vol. 25, pp. 283-302, 2004.

[18] R. Heinich, M. Molenda, J. D. Russell, and S. E. Smaldino, Instruction media and technologies for learning. New Jersey: Englewood Cliffs, 1996.

[19] Widiastuti, "Using game approach in improving learning outcomes of pencak silat." Asian Social Science, vol. 10, no. 5, pp. 168-172, 2014.

T. Muhtar, A. Suherman, A. K. Jayadinata, "The development of a character education model through pencak silat teaching in elementary schools. IJCTA, vol. 9, no. 35, pp. 165-172, 2016. 